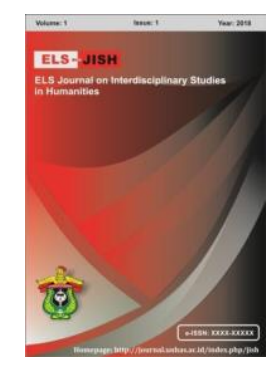

ELS-JISH

ELS Journal on Interdisciplinary Studies on Humanities

Volume 3 Issue 4, 2020

ISSN (print) : 2621-0843

ISSN (online) : 2621-0835

Homepage : http://journal.unhas.ac.id/index.php/jish

\title{
Transitivity Processes in Thunberg's Viral Speech: A Systemic Functional Linguistics Study
}

\author{
Hesti Raisa Rahardi ${ }^{1 *}$, Eva Tuckyta Sari Sujatna ${ }^{2}$, Heriyanto ${ }^{3}$ \\ 1hestiraisaa@gmail.com
}

\begin{abstract}
This study analyses the relationship between clause structures and social construction of the meaning found in verbal speeches. Drawing on Halliday's transitivity system particularly the processes element rooted in Systemic Functional Linguistics, the present study attempts to investigate the distribution of transitivity processes found in viral speech of Greta Thunberg at 2019 United Nation Climate Summit held in New York City. Moreover, through descriptive qualitative analysis, the study aims to reveal the function expressed by the processes found in the speech. To this end, it is found that only five out of six process types namely material, mental, relational, verbal, and behavioral processes found in the speech. Moreover, Thunberg used relational processes, mental processes, and material processes more than verbal processes and behavioral processes. The five processes further serve different functions in the speech. Yet, all of the processes occurred in the speech are generally used to deliver Thunberg's critics over the world leader's slow response in handling the climate issue. Besides, the processes also used to convince the audience and people in general to start doing something for the climate. The implication of this research is expected to give the information on how language structure is used by the environmental activist in her agenda to persuade people.
\end{abstract}

Keywords: Transitivity system, Processes types, Thunberg's viral speech, Systemic Functional Linguistics

\begin{tabular}{l}
\hline How to cite: Rahardi, H., R., Sujatna, E., T.,S., \& Heriyanto (2020). Transitivity Processes in \\
Thunberg's Viral Speech: A Systemic Functional Linguistics Study. ELS-Journal on \\
Interdisciplinary Studies in Humanities, 3(4), 607-614. DOI: \\
https://doi.org/10.34050/elsjish.v3i4.10696
\end{tabular}

\section{Introduction}

In summer 2018, Greta Thunberg is recognized as a kid who skipped school to sit down outside the Swedish parliament building to protest against inaction on climate change. At that time, she began protesting alone and continue her social movement to skip school throughout 2018. A year later, she successfully turned into the leading voice of climate movement and become the center of global climate strike that taken place in more than 150 countries. Moreover, she also received the title as 2019 Time Person of the Year and included into the nomination to win Nobel prize. Her rapid rise to prominence is not only come from her phenomenal one-person protest, but also from her active participation in delivering her message around the world. Concerning

${ }^{123}$ Universitas Padjajaran, Indonesia 
this, many of her speeches have gone viral and made into the headlines. One of them is the speech delivered at UN Climate Summit. Her speech in the summit further attract tons of supportive message along with backlash sent by political figures. Nevertheless, the Greta effect, as the media said, further shows that the ability to influence others can come from the way people implemented their language skill. It caused by the fact that language allows people to do things and be things (Rahman \& Weda, 2019). Yet, in order to achieve the purpose, people should make the design of what they want to say to fit the situation and context at that time Gee (2011). Thus, the choice of words make by the language users can reveal the perspective on how the subject should be represented and it is further enable people to control other's way of thinking (Bhat, 2017). Hence, following the viral issue of Thunberg's speech, this study focuses on analyzing the linguistics elements found in the speech.

There are various approaches that can be used to analyze the lexicogrammatical options made by the language users, but the present study employed Systemic Functional Linguistics in the analysis due to the fact that SFL views language as a strategy to make meaning (Halliday \& Matthiessen, 2014). Moreover, Systemic Functional Linguistics as described by Ravelli in Dalamu (2017) is an approach which has exciting features that can strongly help the researchers in analyzing meaning. The feature is called language metafunctions which include three different terms namely ideational, interpersonal and textual. According to Halliday and Matthiessen (2014) ideational metafunction reflects the real world experiences as perceived by the users. Ideational is realized through transitivity system. Interpersonal metafunction points out the social relations between the addresser and the addressee of a communication which is realized through mood and residue. The last is textual metafunction revealed the construction of the message within a situational context. It is realized through theme and rheme. Yet, considering the focus of the present study is to analyze the linguistics element of Thunberg's speeches which can influence people, transitivity analysis is used.

Halliday and Matthiessen (2014) mention that transitivity consists of three elements namely processes, participant, and circumstances. Out of the three elements, Bloor and Bloor (2004) mentioned that processes are classified as the major element of transitivity. Thus this analysis will be focusing on the processes found in the speeches. Processes refer to the action that is being expressed and it is realized through verbal groups. Participants are the entity who involved in the processes, and circumstances are the element that inform the detail information of the processes. The processes can be further divided into six different types namely material processes, relational processes, mental processes, verbal processes, existential processes, and behavioral processes.

According to Halliday and Matthiessen (2014), material processes cover the tangible action performed by the participants involved in the processes. Unlike material processes, mental processes involve feeling, thinking, and having emotional reactions to thing (Sujatna, 2013). On the other hand, relational processes according Halliday and Matthiessen (2014) are about process of being and having. Verbal processes are described as the process of saying or more accurately, of symbolically signaling (Gerot \& Wignell, 2000). 
Gerot and Wignell (2000) further describe existential processes as the process of existence, while behavioral process cover processes related to human behavior.

Prior to the present study, there are several researches that have been conducted in analyzing speeches using transitivity analysis. One of them is study conducted by Zhao and Zhang (2017) that analyzed processes found in Trump's Inaugural address in 2017. The results show that among the six processes, material processes $(68.6 \%)$ highly dominate the speech. The use of material processes further indicate that material processes are used to paint a bleak picture of America and to describe new actions the government will take. Another study is conducted by Yuqiong and Fengjie (2018) which analyzing David Cameron's speech in order to retain Scotland. The results indicate that relational and material processes are used more than the other process types.

Other researchers who have conducted a speech analysis using transitivity system are Yuliana, Manda, and Darwis (2018) who focused on analyzing Trump's campaign speech and Agbo, Ngwoke, andljem (2019) who studied the process types found in President's Buhari's My Covenant with Nigerians and their functions related to the ideology. From the previous studies, it can be said that most studies focused on analyzing the speech delivered by prominent figures, such as the president and political figures. Yet, to the best of the researcher's knowledge, speech delivered by minority groups has not been explored much. To fill the gap, the present study is conducted to analyze speeches delivered by a young climate activist.

\section{Method}

This research employs descriptive qualitative method in analyzing the processes types found in Thunberg's speeches. The qualitative method is used because the main data of this study are qualitative (Mansyur, 2018; Mansyur \& Said, 2020; Mansyur \& Suherman, 2020). According to Pathak, Jena, and Kalra (2013), qualitative research focuses on people's beliefs, attitudes, and behavior. Qualitative research further does not involve numerical variable, but words. Also, qualitative research is not hypothesis-driven so it is appropriate to use qualitative method to find out the answer concerning experiences, meaning, perspective, and standpoint of the participant (Hammarberg, Kirkman, \& Lacey, 2016). Thus, in order to present the credibility, in qualitative analysis, the researcher should provide explanation that can back up the statement made based on the results. The researcher also involve in the analysis as an important variable. In the present study, the qualitative research is used to analyze and explain the type and function of transitivity processes used by Greta Thunberg in her viral speech.

The data for the analysis is taken from the transcription of Thunberg's speech delivered at UN Climate Summit provided by NBC news (2013). This particular speech is chosen since it gets highlighted more by the press compared to her other speeches. Moreover, this speech is more familiar in public eye and seems to be considered as Thunberg's most iconic speech so far. After collecting the data, the research further divide the clause complexes into clauses since transitivity analysis deals with clauses. Following this, the 
data analysis will be performed in several steps. The first step is analyzing the process types found in Thunberg's speeches. After all the processes are identified, the number of each process type is counted and the percentage of each process is calculated to find out which process types occurred more than the others. After that, the researcher investigates the function of the processes found in the speech.

\section{Findings}

As has been previously mentioned, the present study is conducted to analyze the process types found in Thunberg's speech at UN Climate Summit and the function of the process types. Based on the result, it is found that Thunberg utilized five out of six processes types in her viral speech. Out of five process types, relational processes and mental processes are the process types that take the highest proportion in the speech with $39,7 \%$ and $30,2 \%$ respectively. Following this, Thunberg also used a lot of material processes with $18.8 \%$. Meanwhile, the last two processes namely verbal processes and behavioral processes only take $7.5 \%$ and $3.8 \%$ respectively. Hence, it can be said that the occurrences of verbal processes and behavioral processes appeared to be insignificant compared to the major processes. The distribution of process types found in Thunberg's speech is presented in the table below. Following this, the function of process types found in the speeches will be discussed afterwards.

Table 3.1 Process Types Distribution in Thunberg's speech

\begin{tabular}{ccc}
\hline Process Types & Number of occurrences & Percentage \\
\hline Relational & 17 & $39.7 \%$ \\
Mental & 16 & $30.2 \%$ \\
Material & 10 & $18.8 \%$ \\
Verbal & 4 & $7.5 \%$ \\
Behavioral & 2 & $3.8 \%$ \\
\hline
\end{tabular}

Table 3.1 above shows the distribution of process types found in Thunberg's speech. It is clear that the speech is delivered mostly through relational processes, mental processes, and material processes. Yet, out of three major processes, relational processes take the highest proportion with $39.7 \%$. Concerning this, relational process type is the process type which cover the process of being and having. The process of being and having are shown through the identity or the quality assigned to the participants. Thus, in the speech, relational processes are used to describe the situation concerning the climate change. Greta used words that imply crisis when describing the situation at the present time. The examples of relational processes found in the speeches can be seen in the excerpts below.

a. This is all wrong. I shouldn't be up here. I should be back in school on the other side of the ocean

b. Ecosystem is collapsing

c. You are failing us 
In the example above, Thunberg employed relational processes to point out that the earth is in bad situation and people just made it worse. She start by mentioning how the situation forced her to do something out of her routine. Moreover, to emphasize her point, she used attribute that implying crisis in describing the things related to climate change, such as collapsing, dying, suffering. The use of the expression that imply crisis as attribute can help her in creating dramatic vision to the audience, since people connect to emotion more than words. According to Panksepp in Tyng, Amin, Saad, and Malik (2017), emotion can help increasing human attention and enhances awareness. Therefore, describing the situation through dramatic expression is expected to have bigger impact on the audience and can persuade them to act. However, relational processes are used not only to describe the situation concerning the climate change, but also used to critique the world's leaders through mentioning that they failing children since they appeared to be ignorant and fail to do their job in doing climate change prevention to protect next generation.

Mental processes are the next process type which has higher frequency compared to the other processes in Thunberg's UN speech. Mental process deals with the process of thinking and feeling. Thus, the process will relate to human emotion and cognition. In the analysis, mental process is used in repetition How dare you, the catchphrase that make her speech become viral. Through this catchphrase, Thunberg addressed her disappointment and anger towards the world's leader. Moreover, the use of the catchphrase before mentioning her point helps her to gain the attention of the audience, so it is easier to deliver the message. Moreover, mental process are used to express her declining trust in adults. Mental processes found in the speech can be seen below.

d. You say you hear us

e. And you understand the urgency

f. And I refuse to believe

g. They also rely on my generation

The declining trust is showed through the contradictory description expressed by the mental processes concerning the adults. In one of the examples, the adults or the world's leader are said to do their job by listening to people's concerning the climate change. They also mentioned to understand the importance of solving the climate problem. Through this description, we can say that the adults are said to be reliable and people do not have to worry since the governments will do something about it. However, Thunberg express her refusal to believe in the adults since she points out that the trustworthy image that they displayed is not reflected in their action. The adults said to be rely on the next generation instead of doing their best to prove their image. The distrustful image of the adults further encourage people to not being gullible over everything and start to doing research concerning the climate change.

The third process type found in Thunberg's UN speech is material processes which deal with tangible action that is perfomed by the actor involved in the process. In Thunberg's speech, material processes are mostly used to 
picture the government and world leaders in negative way. At the same, Greta pictured people especially youth as the powerful one. The excerpts below illustrate how the worlds leaders are portrayed negatively and how youth are potrayed as active agent of change.

h. You have stolen my dreams and my childhood with your empty words.

i. Yet you all come to us young people for hope.

j. We will not let you get away with this.

In the speech, the adults or in this case, the world leaders are portrayed as the bad guy who stole children's dreams despite their job is to protect children from any harm. The adults also said to not only stole the future of the children but also leave the problem that cannot be solved to children instead of doing everything they can do in order to give better environment. On the other hand, the portrayal of youth as the powerful party is expressed through mentioning them as one who is expected to solve the problem. Additionally, the children and youth are positioned as the person who check the work of the government and the world leaders.

The least used processes in Thunberg's UN speech are verbal and behavioral processes. Verbal processes concern with the process of saying, quoting, or stating. The sayer or the participant involved in verbal processes found in Thunberg speech are mainly the adults. Greta Thunberg mentioned what statement that is made by the government and the world's leaders during their public appearances as exemplified below:

k. You say you hear us

I. How dare you continue to look away and come here saying that you are doing enough

Yet, alongside the relational processes, verbal processes indicate that the government only talk about climate change, but then put their attention and efforts into other things. As showed in the example above, the government claimed that they have done their best in handling the climate issue. Yet, the climate keeps getting worse.

Meanwhile, behavioral processes that deal with human behavior emphasize the importance of prevent the bad scenario because of climate change. The only behavioral processes found in Thunberg speech is we who have to live with the consequences. Through behavioral processes, Thunberg mentioned that there is no other place for human to continue living besides the earth. Therefore, from now on, people should do some action to take care and save the only place we know that harbors life, so in the future, people do not have to experience and live in the worse scenario based on today's condition.

\section{Conclusion}

The present study used transitivity system proposed by Halliday in Halliday and Matthiessen (2014) to analyze the processes types found in Thunberg's viral speech delivered during UN Climate Summit in New York. Moreover, the analysis also aims to find the functions of the processes occurred in the speech. The result shows that five out of six processes can be found in 
the speech. Yet, the process types which take the largest proportion are relational speeches followed by mental processes and material processes. On the other hand, verbal processes and behavioral processes are the two processes that occurred less than the major processes.

All the processes found in Thunberg's speech serve their own functions: however, in general, all of them are employed to deliver Thunberg's critics over the adults, in this case the world leader's slow response in handling the climate change issue. Moreover, the processes also used to persuade people to start taking action that can save the earth. This general ideas are expressed through different ways. Relational processes are mostly used to describe the situation, Mental processes are used to expose her thought and feeling. Material processes and verbal processes portrayed people as the active agent and associated adults with negative image. Meanwhile, behavioral processes used to urge people to take actions.

\section{References}

Agbo, I. I., Ngwoke, F. U., \& ljem, B. U. (2019). Transitivity processes in president Buhari's 'My covenant with Nigerians.' English Language Teaching, 12(4), 7-14. doi: https://doi.org/10.5539/elt.v12n4p7

Bhat, M., A. (2017). Language: The crucial instrument of social control. Jadavpur Journal of Language and Linguistics, 1(1), 35-41. Retrieved from http://jill.jdvu.ac.in/journal/index.php/JJLL/article/view/4/17

Bloor, T. \& Bloor, M., (2004). The Functional Analysis Of English. London: Arnold.

Dalamu, T. (2017). Systemic functional theory: A pickax of textual investigation. International Journal of Applied Linguistics \& English Literature, 6(3), 187198. doi: 10.7575/aiac.ijalel.v.6n.3p.187

Gee, J. P. (2011). An introduction to discourse analysis: Theory and method. London: Routledge.

Gerot, L., \& Wignell, P. (2000). Making sense of functional grammar. Toronto: Pippin Publishing.

Halliday, M. A. K., \& Matthiessen, C. M. I. M. (2014). Halliday's introduction to functional grammar (4th ed). UK: Routledge.

Hammarberg, K., Kirkman, M., \& de Lacey, S. (2016). Qualitative research methods: when to use them and how to judge them. Human Reproduction, 31(3), 498-501. doi: https://doi.org/10.1093/humrep/dev334.

Mansyur, F. Alamsyah. (2018). Onina Manga Mancuana Mangenge: Ungkapan Tradisional Orang Wolio. Disertasi. Yogyakarta: Pascasarjana FIB UGM.

Mansyur, F. A., \& Said, R. (2020). A Cognitive Semantics Analysis of Wolio Proverbs Related to the Human Body. Advances in Social Science, Education and Humanities Research, volume 436, Published by Atlantis Press SARL, Doi: https://doi.org/10.2991/assehr.k.200529.053 .

Mansyur, F. A., \& Suherman, L. A. (2020). The Function of Proverbs as Educational Media: Anthropological Linguistics on Wolio Proverbs. ELS 
Journal on Interdisciplinary Studies in Humanities, 3(2), 271-286. https://doi.org/10.34050/els-jish.v3i2.10505

NBC News. (2019, September, 23). Read Greta Thunberg's full speech at the United Nations climate action summit. Retrieved from https://www.nbcnews.com/news/world/read-greta-thunberg-s-full-speechunited-nations-climate-action-n1057861

Pathak, V., Jena, B., \& Kalra, S. (2013). Qualitative research. National Center for Biotechnology Information, 4(3), 192-194. doi: 10.4103/22293485.115389

Rahman, F., \& Weda, S. (2019). Linguistic Deviation and The Rhetoric Figures In Shakepeare's Selected Plays. XLinguae, 12(1), 37-52.

Sujatna, E. T. S. (2013). Understanding systemic functional linguistics. Bandung: Unpad Press.

Tyng, C., M., Amin, H., U., Saad, M., N., M., Malik, A., S. (2017). The influences of emotion on learning and memory. Frontiers in Psychology, 8, Article 1454. doi: https://doi.org/10.3389/fpsyg.2017.01454

Yuliana, Y., Manda, A., M., \& Darwis, K. (2018). Transitivity and ideology in Donald trump campaign speech. Journal Ilmu Budaya, 6(1), 154-166. Retrieved from http://journal.unhas.ac.id/index.php/iib/article/view/4320/2458

Yuqiong, Z., \& Fengjie, L. (2018). Transitivity analysis of David Cameron's speech in retaining Scotland. International Journal of Language and Linguistics, 6(3), 70-79. doi: 10.11648/j.ijla.20180602.11

Zhao, M., \& Zhang, Y. (2017). A Transitivity Analysis of American President Donald J. Trump's Inaugural Address. International Journal of Liberal Arts and Social Science, 5(5), 31-43. doi: 10.5176/2251-3566_L317.62 